\title{
Efficiency Assessment of Support Mechanisms for Wood-Fired Cogeneration Development in Estonia
}

\author{
Anna Volkova, Department of Thermal Engineering, Faculty of Mechanical Engineering, Tallinn University of \\ Technology, Andres Siirde, Department of Thermal Engineering, Faculty of Mechanical Engineering, Tallinn \\ University of Technology
}

\begin{abstract}
There are various support mechanisms for woodfired cogeneration plants, which include both support for cogeneration development and stimulation for increasing consumption of renewable energy sources. The efficiency of these mechanisms is analysed in the paper. Overview of cogeneration development in Estonia is given with the focus on wood-fired cogeneration. Legislation acts and amendments, related to cogeneration support schemes, were described.

For evaluating the efficiency of support mechanisms an indicator - fuel cost factor was defined. This indicator includes the costs related to the chosen fuel influence on the final electricity generation costs without any support mechanisms.

The wood fuel cost factors were compared with the fuel cost factors for peat and oil shale. For calculating the fuel cost factors, various data sources were used. The fuel prices data were based on the average cost of fuels in Estonia for the period from $\mathbf{2 0 0 0}$ till 2008. The data about operating and maintenance costs, related to the fuel type in the case of comparing wood fuel and oil shale fuel were taken from the CHP Balti and Eesti reports. The data about operating and maintenance costs used for peat and wood fuel comparison were taken from the Tallinn Elektrijaam reports.

As a result, the diagrams were built for comparing wood and its competitive fuels. The decision boundary lines were constructed on the diagram for the situation, when no support was provided for wood fuels and for the situations, when various support mechanisms were provided during the last 12 years.
\end{abstract}

Keywords - cogeneration, combined heat and power, feed-in tariffs, wood fuel.

\section{INTRODUCTION}

Cogeneration is the production of electricity and heat in a single process. When compared to separate energy production, cogeneration is the more energy efficient of the two and results in primary energy savings. Due to the fact that cogeneration is the simultaneous production of heat and power, it becomes crucial for both types of energy to be used appropriately. As concerning power, it may be both used on the spot and transported across great distances; heat, however, may only be used in the vicinity. Thus, the heat energy consumer is considered the determining factor in selecting cogeneration plant capacity.

A district heating system makes it possible to join heat consumers and as a result the inhabited areas have sufficiently high heat loads to justify the installation of an efficient cogeneration facility.
District heating systems are typical for small and big cities of Estonia, which is why there is a high potential for cogeneration plant installation in Estonia.

According to the Estonian National Development Plan of the Energy Sector until 2020 it should be ensured that by the end of the period of the plan (2020) the electricity produced in cogeneration stations forms $20 \%$ of the gross consumption [1].

Wood can be used for electricity production in the cogeneration plants. Wood fuel has several advantages over fossil fuels.

The main advantage is that wood is a renewable resource, offering a sustainable and dependable supply. This fuel is considered to be carbon neutral. Wood fuel contains minimal amounts of sulphur and heavy metals. Besides, wood is a local fuel in Estonia, and it is usually significantly less expensive than the available fossil fuels. However, there are some disadvantages of using wood energy. The main disadvantages of wood fuel utilization are the high transportation and storage costs.

The development perspectives for wood-fired small-scale cogeneration in Estonia are determined by the necessity for additional energy sources, wood resource availability and the high potential for small-scale cogeneration development in Estonia's small towns.

There are different support mechanisms for wood-fired cogeneration plants, which include both support for cogeneration development and stimulation for increasing the consumption of renewable energy sources. The efficiency of these mechanisms is analysed in the paper.

\section{COGENERATION IN ESTONIA}

Implementation of cogeneration technologies in Estonia began already more than 70 years ago, and this technology was being used both in the Tallinn and in Narva power plants.

The share of cogeneration heat is $30 \%$ of the total heat production in Estonia. The electricity produced in Estonia by cogeneration makes up $12-14 \%$ of the total electricity produced. The share of cogeneration comprised $10 \%$ of the final energy consumption during the last two years and earlier it had been in the range of 14-15\% (Figure 1). This can be explained by the general economic downturn caused by the economy crisis due to which the output of some large industrial cogeneration plants has decreased or even ceased. At the same time, several new small plants have been opened but their energy output is relatively small. At present, the entire electricity sector in Estonia is dominated by the state- 
owned company AS Eesti Energia. There are only some private-owned companies dealing with small-scale cogeneration and some industrial cogeneration plants. The four big cogeneration plants: Balti, Iru, Eesti and Ahtme with a total electrical power of $460 \mathrm{MW}$, are owned by AS Eesti Energia. Thus, there are no problems related to the sale of the electricity produced to the grid. Heat consumers of the AS Eesti Energia cogeneration plants include the district heating networks and industries.

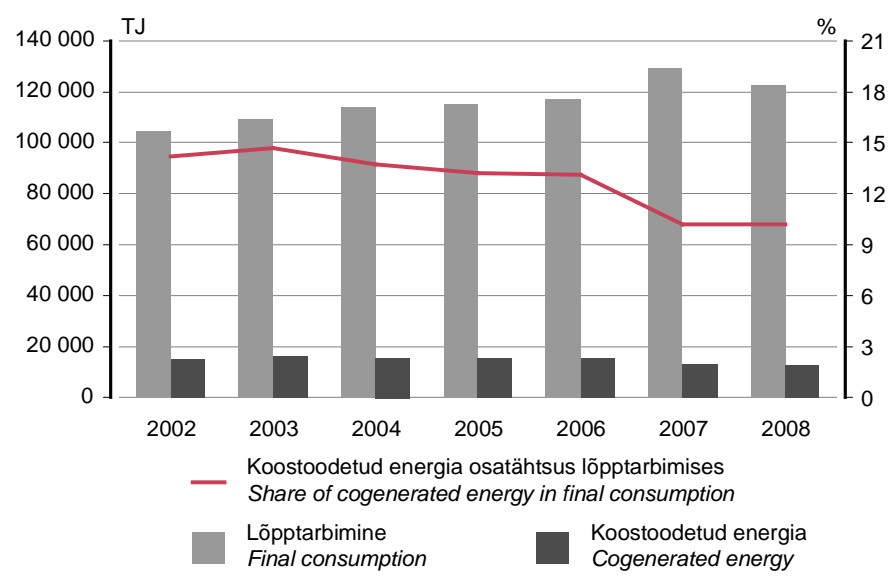

Fig. 1. Cogeneration energy in Estonia [2]

The main fuel types used by cogeneration in Estonia are oil shale (up to $85 \%$ ), natural gas $(11 \%)$, heavy oil, industrial gas $(1 \%)$, and peat $(2 \%)$. There were no wood-fired cogeneration plants in Estonia before 2009. In the beginning of 2009, two new wood-fired CHP units were put into operation (Table 1). Both wood chips and peat can be used as fuel for energy production in these plants.

TABLE I

WOOD-FIRED COGENERATION PLANTS IN ESTONIA

\begin{tabular}{|l|l|l|}
\hline Title & Tartu Elektrijaam & Tallinn Elektrijaam \\
\hline $\begin{array}{l}\text { Beginning of } \\
\text { operations }\end{array}$ & January, 2009 & December, 2008 \\
\hline Electricity capacity & $25 \mathrm{MW}$ & $25,4 \mathrm{MW}$ \\
\hline Heat capacity & $52 \mathrm{MW}$ & $50(68) \mathrm{MW}$ \\
\hline $\begin{array}{l}\text { Planned annual heat } \\
\text { output }\end{array}$ & $158 \mathrm{GWh} /$ year & $304 \mathrm{GWh} / \mathrm{year}$ \\
\hline $\begin{array}{l}\text { Planned annual } \\
\text { electricity output }\end{array}$ & $180 \mathrm{GWh} /$ year & $500 \mathrm{GWh} /$ year \\
\hline
\end{tabular}

\section{III.SUPPORT MECHANISMS FOR COGENERATION IN ESTONIA}

Policy in the field of wood fuel-based combined heat and power production is influenced by the European Union and local Estonian legislation.

According to the EC Directive 2001/77/EC on the promotion of electricity produced from renewable energy sources in the internal electricity market, an indicative target of 21 percent was established for renewable energy sources' share in the total energy consumption of EU members by 2010. After the Commission's re-assessment in 2008, however, the existing policies and measures were estimated to lead to a 19 percent share of renewable energy in the EU's electricity production by 2010 . The directive also defines indicative targets for each member state; the figure for Estonia was $5,1 \%$ by 2010 .

The EU has also adopted measures to promote combined heat and power generation, which are mainly based on the EC Directive 2004/8/EC on the promotion of cogeneration based on a useful heat demand in the internal energy market.

The main targets of the above-mentioned EU directives are reflected in the Estonian Long-Term Development Plan for the Fuel and Energy Sector. The Plan is based on the Sustainable Development Act and is the major strategic document directing the development of the Estonian fuel and energy sector until 2015. According to the plan, the strategic objectives of the Estonian fuel and energy sector include increasing the share of renewable electricity up to $5,1 \%$ of the gross consumption by 2010, and increasing the share of electricity produced from combined heat and power production plants up to $20 \%$ of the gross consumption by 2020.

The Electricity Market Act is the most relevant for the legal framework for wood fuel based cogeneration production, as it contains a support scheme both for renewable energy and cogeneration [4].

A scheme, which includes the obligation for the network operators to purchase electricity generated from renewable energy sources, has been in use since 1998. Up until May 2007, the rate of the obligatory feed-in tariff was 51,77 EUR/MWh. For a long period of time Estonia provided a level of support in the form of feed-in tariffs, which was quite close to the range of electricity generation costs. The main idea of such a policy is to offer a moderate profit for the most costefficient plants [3]. This policy would work efficiently in the case of high interest to install new plants, but as a result, no new plants appeared before changes were made in the support schemes.

In 2007 several important changes were made in the support schemes for electricity production from renewable sources and in cogeneration production plants. Earlier, cogeneration had not been supported in Estonia, and the new provisions of the Act stimulated high efficiency cogeneration by electricity purchase obligation and a certain feed-in tariff.

Two alternatives were introduced as options for cogeneration: either to select a combination of purchase obligation with the feed-in tariff; or to only apply for a subsidized tariff.

However, the subsidy system is going to change again from 1 July 2010. Only the subsidized tariff will be used. The subsidy system changes are shown in Table 2.

The operation of a wood fuel-based cogeneration plant is also affected by the applicable tax laws.

The Environment Charges Act regulates the charges for using natural resources, including pollution charge rates and procedures for calculating and paying them. The rates of pollution charges up to the year 2009 are fixed in the Act. A carbon dioxide charge had to be paid by all enterprises 
producing electricity and/or heat, excluding the ones firing biomass or peat. As of 1 January 2009, all enterprises engaged in the sale of electricity in Estonia must pay an excise duty on electricity instead of the pollution charge for carbon dioxide. The excise duty is determined in the same amount of the pollution charge for carbon dioxide introduced previously [5]. According to the Alcohol, Tobacco, Fuel and Electricity Excise Duty Act, wood fuel and wood charcoal are exempt from the excise duty, which, for example for natural gas is set as $157 \mathrm{kroons} / 1000 \mathrm{~m}^{3}$; for coal, lignite and coke it is 4,7 kroons/GJ [6].

TABLE II

SUPPORT TO COGENERATION IN ESTONIA (EUR/MWH)

\begin{tabular}{|c|c|c|c|}
\hline \multirow[t]{2}{*}{ Period } & \multirow[t]{2}{*}{ Energy Source } & \multicolumn{2}{|c|}{ Tariff alternatives (EUR/MWh) } \\
\hline & & $\begin{array}{l}\text { Compulsory } \\
\text { feed-in tariff }\end{array}$ & $\begin{array}{l}\text { Subsidized } \\
\text { tariff }\end{array}$ \\
\hline \multirow[t]{2}{*}{$\begin{array}{l}1998- \\
2007\end{array}$} & $\begin{array}{l}\text { RES in efficient } \\
\text { cogeneration }\end{array}$ & 51,77 & \\
\hline & $\begin{array}{l}\text { Efficient } \\
\text { cogeneration }\end{array}$ & & \\
\hline \multirow{2}{*}{$\begin{array}{l}2007- \\
2010\end{array}$} & Renewables & 73,50 & 53,69 \\
\hline & $\begin{array}{l}\text { Efficient } \\
\text { cogeneration }\end{array}$ & 51,77 & 31,96 \\
\hline \multirow[t]{2}{*}{$\begin{array}{l}\text { From } \\
2010\end{array}$} & $\begin{array}{l}\text { RES in efficient } \\
\text { cogeneration }\end{array}$ & & 56,67 \\
\hline & $\begin{array}{l}\text { Efficient } \\
\text { cogeneration }\end{array}$ & & $\begin{array}{l}33,33 \\
\text { (only when < }\end{array}$ \\
\hline
\end{tabular}

There are other documents, which circumstantially support the wood fuel-based cogeneration in Estonia: the Development Plan for Promoting the Use of Biomass and Bioenergy 20072013 and the Estonian Rural Development Plan 2007-2013.

\section{IV.EFFICIENCY OF WOOD-FIRED COGENERATION SUPPORT MECHANISMS IN ESTONIA}

The Estonian electricity market has been oriented to one type of fuel - almost $95 \%$ of all electricity is produced from oil shale and the share of other fuels is modest.

Almost certainly the main reasons for that are the availability of oil shale, its low price and the fact, that there are enough installed capacities and a properly functioning infrastructure. The main positive sides of large-scale use of oil shale are the stability of the national energy supply and the independence from electricity import. The main disadvantages of oil shale use are the large-scale environmental damage caused by oil shale mining and the fuel use in the plants, and also the low calorific value of oil shale.

Nonetheless, in spite these disadvantages, oil shale remains the main fuel used for electricity production. The share of renewable resources in electricity production has practically not increased during the last 10 years. The production of electricity from renewable energy sources has increased in recent years, but their share in the total production of electricity is very low. As for wood use for electricity production, the share of it has grown too -- but very slowly.
The wood was used in co-firing process in large-scale oil shale power plants (Figure 2).

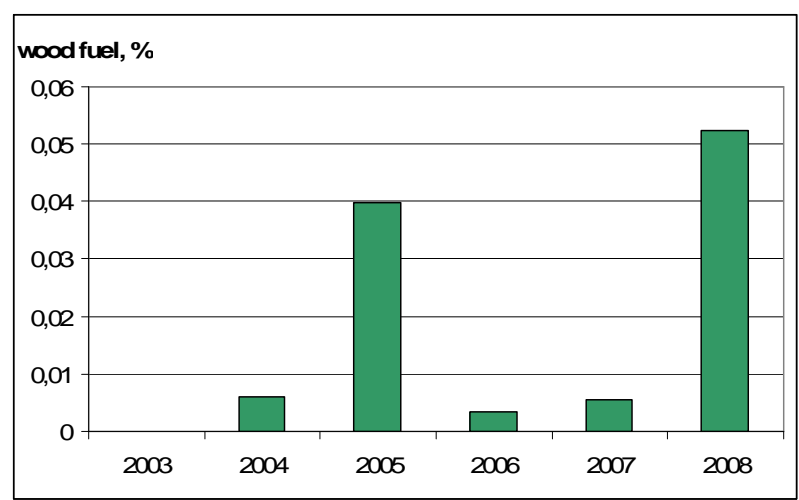

Fig. 2. Wood fuel share in electricity production in Estonia.

There were no wood fuel-fired cogeneration plants before 2007, when only the 51,77 EUR/MWh compulsory feed-in tariff system was used for the electricity produced from renewable energy sources. Feed-in tariffs did not take effect on the wood fuel-fired cogeneration development in the country in this period.

When aforementioned amendments in the Electricity Market Act had been made in 2007, two new wood-fired cogeneration projects started, which resulted in an increases in the wood fuel use for electricity production up to $2 \%$ in 2009 . New cogeneration plants on wood and peat are under preparation in Pärnu (20 MWel), Ahtme (20 MWel) and Viljandi (10 MWel). The usage of wood fuel has also been increased in two of the AS Eesti Energia power plants - in the Balti and the Eesti power plants.

New amendments to the Electricity Market Act concerning electricity production from biomass come into force from 1 July 2010, which will result in biomass use being reduced in Eesti Energia power plants. According to the old version of the Act, the producer had the right to sell electricity as a fixed supply or to receive support for the electricity supplied and sold to the network if it had been generated from a renewable energy source with a generating installation. But after the new amendments come into force, these support mechanisms will only operate for electricity produced from renewable resources (with the exception of biomass) and for electricity produced in an efficient cogeneration regime. It will not be possible to get support in case electricity is produced from biomass in the condensation regime.

\section{WOOD FUEL COMPARED WITH COMPETITIVE FUELS}

The main factors, which influence the final decision according to which the choice of fuel for electricity production by cogeneration is made are: the expenses, related to the fuel price; taxes; and fuel use.

There are several fuels, which compete with wood: oil shale, natural gas and peat.

As it was mentioned before, oil shale is a traditional fuel for the Estonian energy sector. It can be used in big power plants. It is possible to use wood together with oil shale in the co- 
firing process. AS Eesti Energia two circulating fluidised bed energy units in the Balti and the Eesti power plants are flexible and can burn different fuels, and up to $10 \%$ of oil shale can be replaced with wood. To a lesser extent, biomass can, if suitably prepared, also be burned in the old pulverized combustion furnaces. The first trials of burning wood together with oil shale were conducted in 2008 [7].

Other fuel, which is used in cogeneration plants in Estonia, is natural gas. Special technologies are needed for wood and natural gas co-firing. Currently, there are no such plants in Estonia. Usually the main advantage of natural gas in comparison to wood fuel is the low cost of its use, because the fuel preparation and storage expenses for the electricity producer are low.

Peat is a local fuel, which can compete with wood as well. It is possible to use wood and peat in the co-firing process in small-scale cogeneration. Peat is usually cheaper and has a higher calorific value than wood, however peat is considered a fossil fuel, which means that this fuel is not carbon neutral.

Advantages and disadvantages of fuels, which compete with wood fuel for use in cogeneration in Estonia are systematized and shown in Table 3.

TABLE III

ADVANTAGES AND DISADVANTAGES OF FUELS IN COMPARISON WITH WOOD FUEL

\begin{tabular}{|c|c|c|}
\hline Fuel & Advantages & Disadvantages \\
\hline Oil shale vs. wood & $\begin{array}{l}\text { Cheap } \\
\text { Available } \\
\text { Currently working } \\
\text { plants }\end{array}$ & $\begin{array}{l}\text { Environmental } \\
\text { damage } \\
\mathrm{CO}_{2} \text { emission } \\
\text { Can use only in } \\
\text { large-scale } \\
\text { cogeneration }\end{array}$ \\
\hline Natural gas vs. wood & $\begin{array}{l}\text { Little storage and } \\
\text { preparation expenses }\end{array}$ & $\begin{array}{l}\text { Expensive } \\
\mathrm{CO}_{2} \text { emissions } \\
\text { Imported }\end{array}$ \\
\hline Peat vs. wood & $\begin{array}{l}\text { Cheap } \\
\text { Available } \\
\text { Higher calorific } \\
\text { value } \\
\text { Reduces ash } \\
\text { problems }\end{array}$ & $\begin{array}{l}\mathrm{CO}_{2} \text { emissions } \\
\text { Destruction of } \\
\text { biotop } \\
\text { Slow renewability }\end{array}$ \\
\hline
\end{tabular}

\section{VI.METHODOLOGY}

It should be evaluated, how the support mechanisms influence wood fuel cogeneration development in Estonia.

Despite the potential for solid biomass electricity in Estonia, there has been little development in this sector.

The main indicator of support mechanism efficiency is the intensity of usage of the supported energy source. It means, that the support mechanisms stimulate the energy producer to choose a supportable fuel, in this case - a wood fuel.

In case there is no support mechanism and in case technology allows the choice of different fuels, the producer usually chooses the fuel, the use of which will result in lower expenses for energy production. Prior to the new cogeneration plant installation, the energy producer should choose the technology, the use of which would result in lower expenses and would make the project more profitable.

There are different types of electricity generation costs related to the fuel.

First of them is the fuel price, which is changing all the time. The cheapest fuel type in Estonia is oil shale. This fact can be explained by its wide availability and large oil shale production capacities installed in Estonia.

Prices for wood fuel have been rising rapidly over the past several years, which can be explained by increased wood use in Estonia and a rising demand for wood fuel. This is also related to the fact that AS Eesti Energia has started to use wood fuel in its oil shale power plants.

Natural gas is an imported fuel and its price is defined by a foreign provider.

Besides, there are operating and maintenance costs, not connected with fuel price but which depend on the fuel type used. These costs include the fuel preparation expenses, the storage expenses, etc. The expenses are very small for natural gas, and are rather high for oil shale, peat and wood.

The capital costs include the plant installation costs, the storage facility costs, and the fuel preparation equipment costs. These costs differ for wood and fossil fuels.

In order to evaluate the efficiency of support mechanisms, it is important to define an indicator. This indicator should show how the costs related to the chosen fuel influence the final electricity generation costs without any support mechanisms.

Costs related to the specific fuel type include both direct and indirect fuel costs. The direct fuel cost is the fuel purchase price, and the indirect fuel costs are the capital costs, related to the chosen technology, the operating and the maintenance costs, which refer to the fuel type.

As it has been mentioned before, oil-shale / wood and peat / wood co-firing technologies are used in Estonia. It means that the producer chooses the fuel based upon the fuel price and operating and maintenance costs. These costs are used for calculating the fuel cost factor for comparing wood and competitive fuels. It is difficult to allocate the capital costs for two types of fuel in case of co-firing. Usually it is considered, that the capital costs are the same for the fuels used in the cogeneration process. The only exception is, when some additional equipment for the fuel preparation process is necessary. The common formula used for the fuel cost factor calculation (1):

$$
F_{f u e l}=P_{f u e l},+\Delta_{f u e l}
$$

where

$F_{\text {fuel }}$ is the fuel cost factor, $\left(\mathrm{EUR} / \mathrm{MWh}_{\text {fuel }}\right)$;

$\Delta_{f u e l}$ - difference between indirect wood fuel costs and indirect assessed fuel costs, per $1 \mathrm{MWh}$ fuel consumed $\left(\mathrm{EUR} / \mathrm{MWh} \mathrm{h}_{\text {fuel }}\right)$;

$P_{\text {fuel }}$, is the fuel price $\left(\mathrm{EUR} / \mathrm{MWh}_{\text {fuel }}\right)$.

Natural gas and wood fuel co-firing technology is an innovative technology, which is not yet commercially 
available. For this reason, the energy producer has to choose the basic fuel type either from natural gas or from wood fuel before the cogeneration plant installation. As a result, the assessment of the efficiency of support mechanisms can only be realised after long period.

Wood fuel cost factors will be then compared with peat and oil shale fuel cost factors.

In the case of wood/peat co-firing, the same equipment is used for both storage and preparation. For comparison, only the fuel prices will be taken into account. But in the case of oil shale / wood co-firing, some special wood fuel preparation equipment is required. The necessity of installation of additional equipment for adding the renewable fuel in the process reduces the wood fuel competitiveness. For comparing wood fuel and oil shale fuel in the co-firing process, the difference between the preparation costs of the corresponding fuels was added.

For calculating the fuel cost factors, various data sources were used. The fuel prices data were based on the average cost of fuels in Estonia for the period from 2000 till 2008 [8].

The data about operating and maintenance costs, related to the fuel type in the case of comparing wood fuel and oil shale fuel were taken from the CHP Balti and Eesti reports. The data about operating and maintenance costs used for peat and wood fuel comparison were taken from the Tallinn Elektrijaam reports.

For the evaluation of the support mechanism's efficiency, diagrams should be constructed, where the horizontal and vertical axes will show fuel cost factors. Wood fuel and fossil fuel cost factors for the same time periods will be shown in the form of crossing points, but the influence of support mechanisms will be shown in the form of decision boundary lines.

\section{RESULTS AND DISCUSSION}

As a result, the diagrams were built for comparing wood and its competitive fuels. The diagram in Figure 3 indicates the comparison process of wood fuel and peat.

The diagram in Figure 4 was built for comparing wood fuel and oil shale. The wood fuel cost factor is on the horizontal axis and the competitive fuel factor (for peat on Figure 3, for oil shale on Figure 4) is on the vertical axis. Points on these diagrams show the two fuel cost factor states in different years and are constructed by the crossing of drawn through fuel cost factor points lines, which are parallel with diagram axes. Lines on the diagrams reflect the border of fuel choice, which show the state, when two fuel factors are the same. It means that when the factors' crossing point is under the line, the wood fuel cost factor is higher than the competitive fuel factor and the energy producer will choose the competitive fuel. But when this point is above this line, it is the situation, when wood is more competitive than fossil fuel.

The dark solid line corresponds to the situation when no support is provided for wood fuels.

As it was mentioned before, amongst the main fiscal support mechanisms are the feed-in tariffs. According to Table 2 , feed-in tariffs and support providing conditions changed three times over the last 12 years. Fossil fuels can compete with wood fuel when the fossil fuel cost factor is less than the wood fuel cost factor; and the difference is greater, than the volume of fiscal support.

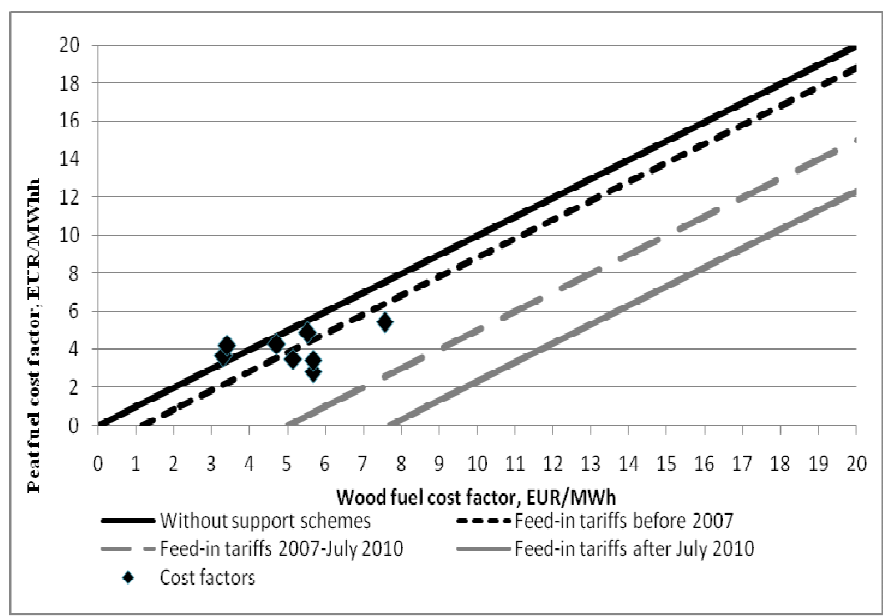

Fig. 3. Decision boundary lines in the case of various support schemes for electricity production from wood fuel. Comparison of wood fuel and peat fuel cost factors.

When comparing the feed-in tariff provided before 2007 with the electricity generation costs at that time, it can be concluded that the government support for electricity produced from wood fuel was approximately 5 EUR/MWh.

During the period from 2007 to July 2010, it was possible to get support for electricity production using the efficient cogeneration technologies (subsidized feed-in tariff 31,96 EUR/MWh) and using the fossil fuel, and also for electricity production from wood fuel (subsidized feed-in tariff 53,69 EUR/MWh). In the case of the comparison of peat and wood use in cogeneration, the difference in support is 21,73 EUR/MWh el. In the case of comparison of oil shale and wood use, the difference in support is 53,69 EUR/MWh. Starting from 2010, the difference 33,34 EUR/MWh between subsidized feed-in tariff for renewable cogeneration and peat cogeneration was used for the calculations by peat and wood fuel comparison. As regarding electricity production from wood when the cogeneration process is not fully efficient, there is no more support provided from 2010. These data were used for construction of the decision boundary lines. There are different energy electricity efficiency coefficients for wood/peat and oil shale/wood cogeneration technologies. The feed-in tariffs are provided for electricity production, but the fuel cost factors are calculated for the fuel energy used for production. For this reason, the decision boundary lines are different in the diagrams for peat and for oil shale.

As it can be seen from figures 3 and 4 , the efficiency of support in the form of feed-in tariffs before 2007 was very low; this is shown by the dark dashed lines. Wood could not compete with oil shale, in some cases it could compete with peat. But there were many cases, when it was more profitable to use peat rather than wood in the co-firing process. Some points are still located under the decision boundary line. There 
was no special support for cogeneration, which is why no new renewable power plants were installed before 2007. Feed-in tariffs in the period from 2007 to July 2010 are depicted in the form of a bright dashed decision boundary line. All points both in Figure 3 and e Figure 4 are located above this line, which shows that the producer's choice will be wood fuel. Feed-in tariffs, which start to work in July 2010, refer to peat and wood fuel co-firing, and it provides an even more profitable situation for the wood fuel (the bright solid line, Figure 3). Even if peat becomes cheaper and wood becomes more expensive, the wood fuel will still be able to compete with peat within the whole application period of this scheme. As regarding the support scheme in the case of comparison of oil shale and wood, the main difference is that it is not possible to provide an efficient cogeneration regime in the oil shale power plants. Thus, the feed-in tariffs used for the renewable cogeneration energy support after July 2010, were not taken into account.

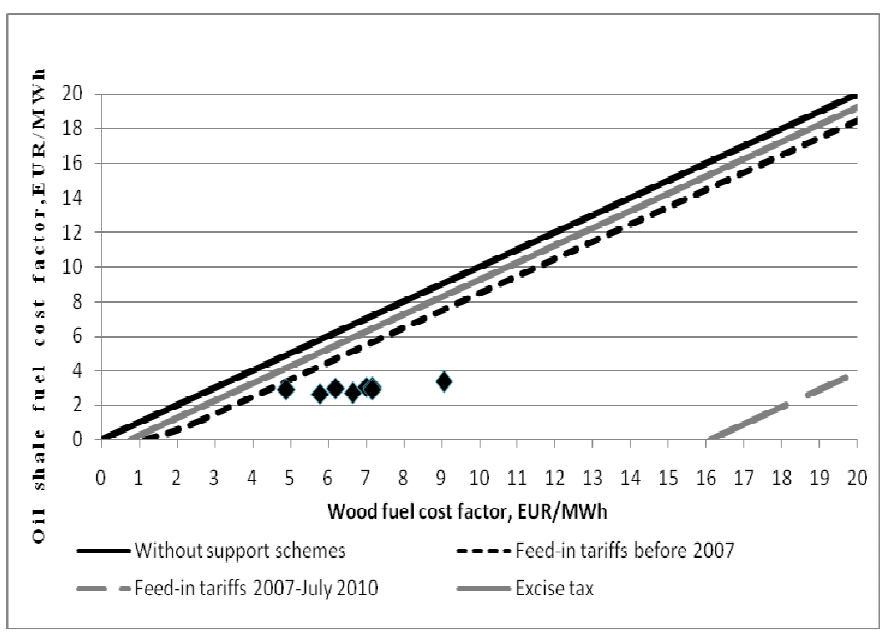

Fig. 4. Decision boundary lines in the case of various support schemes for electricity production from wood fuel. Comparison of wood fuel and oil shale fuel cost factors.

Taxes are also used as support mechanisms for wood fuel. The tax-based support scheme applies for the peat as well, which is why this support scheme does not improve the competitiveness of wood compared to peat.

Wood fuel can compete with oil shale, when the oil shale cost factor is less than the wood fuel cost factor, and their difference equals at least the environmental taxes volume.

The bright solid line (Figure 4) reflects the decision boundary line when only the excise tax is used; that shows the situation when it is not possible to produce electricity in an efficient cogeneration regime, using the oil shale and wood fuel co-firing technology in big power plants. It can be seen that all points are still below the line, which means that it is not profitable to use wood fuel for electricity production (Figure 4).

The efficiency of the analysed support schemes is high, but there are various obstacles, that do not yet provide the possibility to develop wood- fired cogeneration in Estonia: the administrative, the social and the financial barriers. There is a lack of stability in the Estonian Energy legislation; the important amendments have been made many times during a relatively short period. High bureaucracy is considered to be one of the obstacles for successful wood-fired cogeneration. The wood fuel supply infrastructure is a question, which should be determined at the government level. It means that, despite the high efficiency of fiscal support mechanisms, as it has been evaluated, there are still many questions that should be resolved for the wood-fired cogeneration development in Estonia.

\section{CONCLUSION}

As a result of the assessment of the wood fuel cost factors for cogeneration in Estonia, it was concluded that wood-fired cogeneration heat should be supported, because it cannot compete with fossil fuel-based cogeneration without involving support mechanisms. The conditions for providing support to renewable energy and cogeneration changed three times over the last 12 years.

On the one hand, this shows a positive tendency in search for the optimal scheme. It has resulted in elaborating a support system, which is already functioning to the benefit of cogeneration development. On the other hand it indicates that the legislation has not been prepared in every detail from the very start.

In the research the legislation and support schemes and their changes were analysed. For evaluating the efficiency of support mechanisms an indicator - fuel cost factor was defined. This indicator includes the costs related to the chosen fuel influence on the final electricity generation costs without any support mechanisms.

The wood fuel cost factors were compared with the fuel cost factors for peat and oil shale. As a result, the diagrams were built for comparing wood and its competitive fuels. The decision boundary lines were constructed on the diagram for the situation, when no support was provided for wood fuels and for the situations, when various support mechanisms were provided during the last 12 years. The decision boundary lines reflect the border of fuel choice. It means that when the factors' crossing point is under the line, the wood fuel cost factor is more appropriate than the competitive fuel factor and the energy producer will choose the competitive fuel. But when this point is above this line, it is the situation, when wood is more competitive than fossil fuel.

The assessment showed that only the support schemes introduced in 2007 are efficient for wood-fired cogeneration development. Legislation has been recently changed again, which may lead to higher competitiveness of the wood-fired small-scale plants working in a cogeneration mode. However, due to the fact that the large-scale cogeneration plants are being excluded from the support target group, the overall state support volume could also reduce.

Despite the analysed support schemes being efficient, there are still some barriers of an administrative, social and financial nature, which do not yet provide the possibility to develop wood- fired cogeneration in Estonia. 


\section{IX.ACKNOWLEDGMENT}

This work has been partly supported by the European Social Fund within the researcher mobility programme MOBILITAS (2008-2015), 01140B/2009.

\section{REFERENCES}

1. Long-term Public Fuel and Energy Sector Development Plan until 2015 Riigi. Teataja, RT I, 23.12.2004.

2. Truuts H., Raudjärv R., Koostootmine kui energiasäästuvõimalus, Eesti statistika kvartalikiri,. 4/09. Quarterly Bulletin of Statistics Estonia, $4 / 09$.

3. The support of electricity from renewable energy sources, Accompanying document to the Proposal for a Directive of the European Parliament and of the Council on the promotion of the use of energy from renewable sources, Brussels, 23.1.2008.

4. Electricity Market Act, Passed on 11 February 2003, Estonia.
5. Environmental Charges Act, Passed on 17 December 2005, Estonia.

6. Alcohol, Tobacco, Fuel and Electricity Excise Duty Act, Passed 4 December 2002, Estonia.

7. Environmental Report / Eesti Energia Annual Report, 2009/2010.

8. Average cost of fuels and energy consumed by enterprises by type of fuel/energy, FE08, 1998/2008, Statistical Data Base, Statistics Estonia.

Anna Volkova, Dr.Sc.Ing., Postdoc, Researcher

Institute of Thermal Engineering, Tallinn University of Technologies

Address: Kopli 116, 11712, Tallinn Estonia

Phone: +372 6203907, Fax+3726203901

e-mail: anna.volkova@ttu.ee

Andres Siirde, Dr.Sc.Ing., Professor

Department of Thermal Engineering, Tallinn University of Technology

Address: Kopli 116, 11712 Tallinn, Estonia

Phone: 372+ 620 3900, Fax: 372+ 6203901

e-mail: asiirde@sti.ttu.ee

Anna Volkova, Andres Siirde. Koksnes koǵenerācijas atbalsta mehānismu efektivitātes novērtējums Igaunijā

Pastāv dažādi atbalsta mehānismi koksni izmantojošas kog̉enerācijas veicināšanai, kuri iekḷauj gan atbalstu koǵenerācijas attīstībai, gan atjaunojamo energoresursu izmantošanas stimulē̌̌anu. Raksts analizē šo mehānismu efektivitāti un sniedz pārskatu par koǵenerācijas attīstību Igaunijā, īpaši pievēršoties koksni izmantojošai koǵenerācijai. Aprakstīti normatīvie akti un to grozījumi, kas saistīti ar koǵenerācijas atbalsta shēmām.

Atbalsta mehānismu novērtējumam tika noteikts indikators: kurināmo izmaksu faktors. Šis indikators ieklauj izmaksas, kas saistītas ar izvēlētā kurināmā ietekmi uz galīgajām elektroenerǵijas ražošanas izmaksām bez jebkādiem atbalsta mehānismiem. Koksnes kurināmo izmaksu faktori tika salīdzināti ar kūdras un degslānekla izmaksu faktoriem, kuru aprēkiniem tika izmantoti dažādi dati. Kurināmā cenas tika pamatotas uz datiem par vidējām kurināma izmaksām Igaunijā no 2000. gada līdz 2008. gadam. Dati par koksnes un degslānekḷa ekspluatācijas izmaksām, kas saistītas ar izvēlētā kurināmā veidu, tika iegūti no Eesti un Balti elektrostaciju atskaitēm. Salīdzinot koksni ar kūdru, dati par ekspluatācijas izmaksām, kas saistīti ar izvēlētā kurināma veidu, tika iegūti no Tallinas elektrostacijas atskaitēm.

Rezultātā ir iegūtas diagrammas koksnes kurināmā salīdzināšanai ar konkurējošiem kurināmā veidiem: kūdru un degslānekli. Šajās diagrammās ir ievilktas lēmuma pienemšanas robežas līnijas situācijai, kad netiek sniegts atbalsts no valsts puses un situācijām, kad tiek realizēti pēdējo 12 gadu laikā pastāvošie atbalsta mehānismi (iepirkšanas tarifi, nodokli).

Анна Волкова, Андрес Сиирде. Оценка эффективности механизмов поддержки для развития деревосжигающей когенерации в Эстонии Существуют различные механизмы поддержки деревосжигающей когенерации, которые включают в себя как поддержку для развития когенерации так и для стимулирования увеличения потребления возобновляемых энергоресурсов. Эффективность этих механизмов проанализирована в данной статье. Представлен обзор развития когенерации в Эстонии с упором на деревосжигающую когенерацию. Описаны законодательные акты и поправки, связанные со схемами поддержки когенерации

Для оценки эффективности механизмов поддержки был определен индикатор: фактор топливных затрат. Этот индикатор включает затраты связанные с влиянием выбранного топлива на конечные затраты производства электричества без каких либо механизмов поддержки. Факторы топливных затрат древесины сравнивались с факторами топливных затрат торфа и горючих сланцев. Для расчета фактора топливных затрат были использованы различные данные. Цены на топливо были основаны на средней стоимости топлива в Эстонии за период с 2000 года по 2008 год. Данные о затратах на эксплуатационное и техническое обслуживание, связанные с типом топлива в случае сравнения древесного топлива и горючих сланцев, были получены из отчетов станций Балти и Ээсти. Данные о затратах на эксплуатационное и техническое обслуживание, связанные с типом топлива в случае сравнения древесного топлива и торфа, были получены из отчетов Таллинской Электростанции.

Как результат, две диаграммы были построены для сравнения древесины с конкурирующими топливами: торфом и горючими сланцами. На этих диаграммах были сконструированы линии границы принятия решения для ситуации, когда поддержка со стороны государства не оказывается и для ситуаций, когда применяются действующие в течении последних 12 лет различные механизмы поддержки (закупочные тарифы, налоги) 